\title{
Problems with the Territorial Boundary of the Republic of Indonesia - Malaysia in Tanjung Datuk in the 1982 UNCLOS Perspective and the UN Charter
}

\author{
Amora Harris ${ }^{1}$, Dohar Sianturi ${ }^{2}$, Lukman Yudho Prakoso ${ }^{3}$ \\ 1. Student of Sea Defense Strategy Study Program, Indonesia Defense University-Bogor, Indonesia \\ 2. Lecturer of Indonesia Defense University-Bogor, Indonesia
}

\begin{abstract}
The land border between Indonesia and Malaysia has a length of $\pm 2,004 \mathrm{~km}$ stretching from Tanjung Datu in the west to the east coast of Sebatik Island in the east. the joint demarcation of the two countries began in 1973, where up to 2009 there were 19,328 border monuments with coordinates. The delimitation of the RI-Malaysia land boundary, which is mostly in the form of watersheds (mountain ridges or hills, or water dividing lines) has been completed, but demarcation still leaves 9 outstanding boundary problems. Overall, of the 9 OBPs, it appears that 7 OBPs are problems that "harm" the Malaysian side, while 2 problems are detrimental to Indonesia. One of the problems in Tanjung Datu started with the measurement and confirmation of international boundaries that were carried out in 1975 and 1976. The problem is that the measurement technique is inappropriate. This scientific work is expected to provide strategic recommendations in dealing with problems in the Tanjung Datu. This study uses a scientific approach with qualitative descriptive methods and uses UNCLOS and UN Charter as basis review. The results of this study a review of Tanjung Datu border conflict in UNCLOS and UN Charter Prespective. The conclusion of this study is There is a need for concrete agreement between Indonesia and Malaysia about Tanjung Datu because there so many fisherman than depends in this border.
\end{abstract}

Keywords: Territorial Boundary, UNCLOS Perspective and the UN Charter

DOI: $10.7176 /$ PPAR/11-4-07

Publication date:May $31^{\text {st }} 2021$

\section{Introduction}

The land border between Indonesia and Malaysia has a length of $\pm 2,004 \mathrm{~km}$ stretching from Tanjung Datu in the west to the east coast of Sebatik Island in the east. The delimitation of land boundaries with Malaysia refers to the boundary agreement between the British Government and the Government of the Netherlands Indies (Treaty 1891, Conventions 1915 and 1928) as well as the MOU land boundaries between Indonesia and Malaysia 1973-2006. Meanwhile, the joint demarcation of the two countries began in 1973, where up to 2009 there were 19,328 border monuments with coordinates. The delimitation of the RI-Malaysia land boundary, which is mostly in the form of watersheds (mountain ridges or hills, or water dividing lines) has been completed, but demarcation still leaves 9 outstanding boundary problems. Overall, of the 9 OBPs, it appears that 7 OBPs are problems that "harm" the Malaysian side, while 2 problems are detrimental to Indonesia. One of the problems in Tanjung Datu started with the measurement and confirmation of international boundaries that were carried out in 1975 and 1976. The problem is that the measurement technique is inappropriate.

The resolution of RI-Malaysia land border issues has been handled through three institutions, namely: (1) RI-Malaysia General Border Committee (GBC) coordinated by the Ministry of Defense; (2) RI-Malaysia Joint Commission Meeting (JCM), coordinated by the Ministry of Foreign Affairs; and (3) the Technical Survey and Demarcation Sub-Commission is coordinated by the Ministry of Home Affairs. To deal with Outstanding Border Problems (OBP), a Joint Working Group has been formed between the two countries. 


\section{Research Methods and Theories}

This research uses descriptive qualitative method, the regulation used is United Nations Convention Law of The (UNCLOS) 1982 AND UN Charter. UNCLOS 1982 and UN Charter as the main regulation to solve a International conflict in the sea between country

\section{Analysis of the Discussion}

A dispute can be defined as the existence of a specific disagreement about a fact, law or policy in which one party's claim is rejected by another party who makes a different claim. ${ }^{1}$ In a broader scope, international disputes can be defined as disagreements that involve governments, institutions, legal entities, or individuals and cross national borders. In 1945, the founding member states of the United Nations agreed in Article 2 paragraph (3) of the United Nations Charter for

" settle their international disputes by peaceful means in such a manner that international peace and security, and justice, are not endangered [menyelesaikan sengketa internasional dengan cara yang damai sehingga perdamaian dan keamanan internasional serta keadilan tidak terancam]. ${ }^{2}$

Resolusi Majelis Umum PBB pada tahun 1970, setelah mengutip Pasal 2 ayat (3), menyatakan:

“ States shall accordingly seek early and just settlement of their international disputes by negotiation, inquiry, mediation, conciliation, arbitration, judicial settlement, resort to regional agencies or arrangements or other peaceful means of their choice "

Therefore, there is an urgency to know how the mechanisms for peaceful international dispute resolution are encountered in the practice of international relations. In the case of Tanjung Datu there is a boundary problem between Indonesia and Malaysia. Regarding the issue of sea and maritime boundaries, the United Nations has regulated the United Nations Convention Law of the Sea (UNCLOS) 1982. UNCLOS 1982 divides the sea into three parts, namely: First, the sea which is part of its sovereign territory (namely the territorial sea, the inland sea), The two seas which are not its sovereign territory but the country has rights and jurisdiction over certain activities (i.e. additional zones, exclusive economic zones), the three seas which are not its sovereign territory and are not rights / jurisdiction, but the country has an interest, namely the free sea. ${ }^{3}$

According to UNCLOS 1982 in Article 5, it is stated that the width of the territorial sea is measured from the "baseline" and the waters that are in the land direction of the line are stated as inland waters. In certain circumstances another baseline may be used, which will give rise to inland waters. These circumstances are :

1. If the coastline is deeply indented or if there is a line of islands along the coast, a straight baseline can be drawn from certain points on the coast or islands. (Article 7 UNCLOS 1982)

2. If the land is so concave inward that it can be said that there are waters covered by land (in a situation where the area of the indentation is larger than a semicircle with a diameter equal to the width of the mouth of the indentation), the territorial sea can be measured from the cover line drawn on the indentation, provided that the line of cover shall not exceed 24 nautical miles. (Article 10 UNCLOS 1982)

\footnotetext{
${ }^{1}$ J. G. Merills, International Dispute Settlement, New York, Cambridge University Press, 2011, hlm. 1.

${ }^{2}$ United Nations Charter, 1945, Pasal 2 ayat (3)

${ }^{3}$ Retno Windari, Hukum Laut Zona-Zona Maritime Sesuai UNCLOS 1982 dan Konvensi-Konvensi Bidang Maritim, Jakarta, Badan Koordinasi Keamanan laut, 2009, hlm 19.
} 
3. If a river empties directly into the sea, a baseline can be drawn across its mouth by connecting the points on the low water line on the edge of the estuary. (Article 9 UNCLOS 1982)

Above is the basic mechanism of territorial sea withdrawal for a country with clear sea boundaries, which is different from Indonesia, which is an archipelago state or Archipelago State. Archipelagic waters are a maritime zone that is not owned by all coastal countries, but only owned by coastal states which are categorized as archipelagic countries. According to Article 49 UNCLOS 1982 what is meant by Archipelagic Waters are waters covered by Archipelagic Base Line regardless of their depth and distance from the coastline. A country that is categorized as an archipelagic country has full sovereignty in the territorial waters of its archipelago, the air space above it, in the seabed beneath it, under the ground and also over the wealth contained therein. ${ }^{4}$

In the case of Tanjung Datu, Article 15 of the UNCLOS regulates the delimitation of territorial sea boundaries between countries whose coasts are opposite or adjacent, neither of the two countries has the right, unless there is a reverse agreement between them, to determine its territorial sea boundaries beyond the median points are equidistant from the closest points on the baseline from which the width of the territorial sea of each country is measured. ${ }^{5}$ On this basis, the side-by-side territorial problems are resolved by both parties without any intervention with foreign parties. Indonesia can conduct diplomacy with Malaysia regarding this boundary when the previous measurement has been wrongly taken.

With regard to things that are prohibited from being carried out in gray areas or territorial areas of other countries regulated in Article 19 paragraph (1) UNCLOS 1982. This article states that a voyage is said to violate / disturb the peace, rule of law and security of a country if the ship carries out specific activities that include :

1. Any threat or use of force that violates the sovereignty, territorial integrity or political freedom of the coastal state, or violates the principles of international law as stipulated in the UN Charter;

2. Any training or experiment using one type of weapon;

3. All activities to collect information that can be detrimental to the defense and security of the coastal state;

4. Any impacted propaganda actions that have an impact on the defense and security of the coastal state;

5. Aircraft launching, landing and loading;

6. Launching, landing and loading of military equipment;

7. Loading and unloading commodities, currencies or people that are against the immigration, fiscal and sanitation laws of the coastal state;

8. All pollution and pollution that is contrary to UNCLOS;

9. All fishing activities;

10. To carry out research or survey activities;

11. Any actions that can interfere (disrupt) the communication system or facilities or installations of the coastal state;

12. Other activities that have nothing to do with the voyage.

However, in relation to the activities of other countries in archipelagic waters, an archipelagic state also has the responsibility to respect and guarantee the rights possessed by that other country which are determined

${ }^{4}$ Suryo Sakti Hadiwijoyo, Perbatasan Negara Dalam Dimensi Hukum Internasional, Yogyakarta, Graha Ilmu, 2011, hlm 32.

${ }^{5}$ J.G. Starke, Pengantar Hukum Internasional I, Jakarta, Sinar Grafika, 2009, hlm 348. 
on the basis of an official agreement. As stated in Article 51 paragraph (1) UNCLOS 1982, this includes the rights of neighboring countries directly adjacent to archipelagic countries to carry out traditional fishing and other legal activities in certain areas in archipelagic waters. ${ }^{6}$ This is the basis for small fishermen to operate in the gray area between the two countries.

\section{Conclusion}

There is a need for concrete agreement between Indonesia and Malaysia about Tanjung Datu because there so many fisherman than depends in this border. As we know in UNCLOS if the got lost 1 meter of the beach they got lost 16 miles in the sea, that why Indonesia must do something about it

\section{Reference}

J. G. Merills, International Dispute Settlement, New York, Cambridge University Press, 2011, hlm. 1.

United Nations Charter, 1945, Pasal 2 ayat (3)

Retno Windari, Hukum Laut Zona-Zona Maritime Sesuai UNCLOS 1982 dan Konvensi-Konvensi Bidang Maritim, Jakarta, Badan Koordinasi Keamanan laut, 2009, hlm 19.

Suryo Sakti Hadiwijoyo, Perbatasan Negara Dalam Dimensi Hukum Internasional, Yogyakarta, Graha Ilmu, 2011, hlm 32.

J.G. Starke, Pengantar Hukum Internasional I, Jakarta, Sinar Grafika, 2009, hlm 348.

I Made Andi Arsana, Batas Maritim Antarnegara: Sebuah Tinjauan Teknis dan Yuridis, Yogyakarta, Gadjah Mada University Press, 2007, hlm 28.

Author Profile

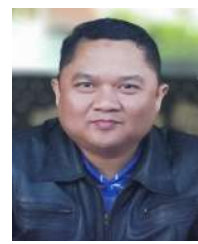

Amora Harris is a postgraduate student for study assignments at the Defense University for the 2020/2021 academic year. He is an officer in the Indonesian Navy and is currently pursuing a marine defense strategy study program at the defense strategy faculty of the Indonesian Defense University. He is interested in maritime security and marine defense related to Indonesia's maritime defense strategy which has recently become a hot issue.

\footnotetext{
${ }^{6}$ I Made Andi Arsana, Batas Maritim Antarnegara: Sebuah Tinjauan Teknis dan Yuridis, Yogyakarta, Gadjah Mada University Press, 2007, hlm 28.
} 